\title{
Effects of Urban Land Use Change on Selected Public Utilities for Sustainable Development in Akure, Nigeria
}

\author{
Francis Omowonuola Akinluyi ${ }^{1}$, Michael Ajide Oyinloye ${ }^{2 *}$, Comfort Opeyemi Aladekoyi ${ }^{3}$ \\ ${ }^{1}$ Department of Remote Sensing and Geoscience Information System, The Federal University of Technology, Akure, Nigeria \\ ${ }^{2}$ Department of Urban and Regional Planning, The Federal University of Technology, Akure, Nigeria \\ ${ }^{3}$ Department of Physical Planning, University of Medical Science, Ondo, Nigeria \\ Email: ^maoyinloye@futa.edu.ng
}

How to cite this paper: Akinluyi, F. O., Oyinloye, M. A., \& Aladekoyi, C. O. (2021). Effects of Urban Land Use Change on Selected Public Utilities for Sustainable Development in Akure, Nigeria. Journal of Geoscience and Environment Protection, 9, 25-39.

https://doi.org/10.4236/gep.2021.95004

Received: April 30, 2021

Accepted: May 22, 2021

Published: May 25, 2021

Copyright ( 2021 by author(s) and Scientific Research Publishing Inc. This work is licensed under the Creative Commons Attribution International License (CC BY 4.0).

http://creativecommons.org/licenses/by/4.0/

\section{(c) (i) Open Access}

\begin{abstract}
Urban landuse change is one of the main driving forces of global environmental change. It is central to the sustainable development debate. The aim of this research is to examine the effects of urban landuse and its impact on selected public utility services in Akure with a view to improve strategies to protect these utilities for sustainable development. The research was conducted using remote sensing, Geographical information System and questionnaire to collect the required data for the purpose of fulfilling the objectives of this study. In this study of analyzing the urban landuse change, 2010 and 2018 IKONOS are used in a post classification comparison analysis to map the landuse changes and identify the conversion process in Akure. The landuse change statistics results obtained revealed that residential landuse has changed rapidly for the periods (2010-2018). The results also show increase in commercial landuses between the same periods. The results of the analysis reveal that the built-up area has been growing rapidly for the periods (2010-2018). Findings show that, housing provision (residential), business purpose (commercial) and educational (institution) are the major causes of land use change in the study areas. To reduce the effect of land use expansion in the study areas, policy measures were recommended which include regulating the growth and spread of development, regional development programs. In our opinion, the information provided by these technologies could help city planners and policy makers to attain and sustain future urban development.
\end{abstract}

\section{Keywords}

Landuse, Public Utilities, Sustainable Development, Remote Sensing, GIS, Satellite Imageries 


\section{Introduction}

Land use refers to the activity, economic purpose, intended use and or management strategy placed on the land-cover type (s) by human agents or land managers. Land cover refers to the characteristics and surface cover of the earth surface as represented by vegetation, water, bare earth, impervious surface and other physical features of the land (Jensen et al., 2003). Land use change occurs when the use to which land is put in different from what it was in past. For instance, an open space or forested area could turn into a built-up area. Therefore, land use and landcover changes play an important role in local and regional environment condition of a particular territory and they are linked to global environmental change (Adebayejo \& Abolade, 2006). Landuse both reflects and defines where economic activity takes place, and where and how communities develop (Goetz, Shortle, \& Bergstrom, 2005). Alonso (1960); Edwards (2007); Kabba \& Li (2011); Uju \& Iyanda (2012); Adegoke (2014) concluded that increase in population elicits a proportionate in the demand for land for residential uses, and the occurrence for commercial, industrial, institutional and transportational landuses is spatially linked to residential development.

The patterns of land use within different urban areas have different forms due to the factors that are shaping this pattern. Such factors include topographical features, legislation and legal decision from the government, social and religious, even customs (land holding system), government policy on public utilities and social services supply (Adeniyi, 1978).

In recent years some scholars have carried out preliminary attempts in this field. Lee, Huang and Chan (2009) adopted a spatial system modeling method for the Taipei Metropolitan Region to simulate the spatial-temporal dynamics of socio-economic metabolism and landuise change. Peng and Howarth (2004) used Satellite imageries for the year 1984, 1997 and 2000; one of the goals of the study was to produce a land use map of Shaoxing City and its surroundings. The results show that there are undoubtedly a lot of changes that occurred between 1984 and 1997 when compared with those of 2000, due to the sufficient time gap.

Similarly, Yin et al. (2005) used image processing and analysis in a GIS environment to assess spatial change in urban land use patterns and population distributions. Here, unsupervised classification was used to classify the images into land use classes. With Census data in a GIS, census polygon was constructed into various sets of units, and then comparison made with the classified image by proportion in surface.

Ramadan, Feng and Cheng (2004) analysed the nature, rate and location of urban landuse changes, urban built-up land was extracted from each of the images, overlaid on each other to obtain an urban expansion image. These extractions were done on layers in the vector GIS environment and the result used to identify urban land change to obtain real time information. Musaogwu, Kaya, Seker and Goksel (2004) incorporated remote sensing and GIS to 
create overlays of two or more independently produced classified images. It can be used to detect changes, trend, location and amount of changes that have occurred. Kamh, Ashmawy, Kilias, and Christaras (2012) used GIS, Remote sensing and principal component analysis to evaluate urban landuse changes in the Hurghada area, Egypt. The results showed that population growth, city location and coastal tourism activities were the major factors driving land use change and expansion. Zubair (2006) examined the use of GIS and Remote Sensing in mapping landuse and landcover in Ilorin, Nigeria between 1972 and 2001 to detect the changes that has taken place in this status between these periods. Appiah, Bugri, Forkuor and Boateng (2014) in Ghana used Pearson's, Chi-square, step-wise logistic regression modeling, GIS and remote sensing to evaluate the effects of peri-urbanization on landuse change patterns. The results indicates that increasing rate of peri-urbanization caused by rising demand for residential, recreational and commercial landuses to the detriment of agricultural landuses.

The objectives of this study include to:

1) Identify the major land use types using remote sensing/GIS in the study area.

2) Estimate the proportion of land for each use in the study area.

3) Analyse the causal factors responsible for landuse change

4) Determine the planning implications of the urban land use change on these selected public utilities in the study area

\section{The Study Area}

The study area is Akure, the administrative capital of Ondo State. The city is located within Ondo State in the South Western part of Nigeria (see Figure 1). It lies approximately on latitude $7^{\circ} 15^{\prime}$ North of the Equator and longitude $5^{\circ} 15^{\prime}$ East of the Greenwich Meridian. Akure is a medium-sized urban centre and became the provincial headquarter of Ondo province in 1939. It also became the capital city of Ondo State and a Local Government headquarters in 1976 (see Figure 2 and Figure 3). The city's morphology has changed over time to assume its present status with its attendant land use problems, as experienced in similar medium sized urban centres in Nigeria. Akure is located approximately $700 \mathrm{ki}-$ lometers South West of Abuja, the Federal Capital of Nigeria and about 350 kilometers to Lagos the former capital of Nigeria. The annual average temperatures range between $21.4^{\circ} \mathrm{C}$ and $31.1^{\circ} \mathrm{C}$, and its mean annual relative humidity is about $77.1 \%$. It is located within the tropical rain forest region of Nigeria where rainfall is high throughout the year. The rapidity of its development within forty two years stemmed from the political status of the city which was initially a provincial headquarters later a state capital thus servicing as the seat of both local and state governments ever since; this accounted for the influx of people into the city for employment. In 1991, the population had risen to 239,124 and by 2006 the population was put at 340,021 (NPC, 2006). 


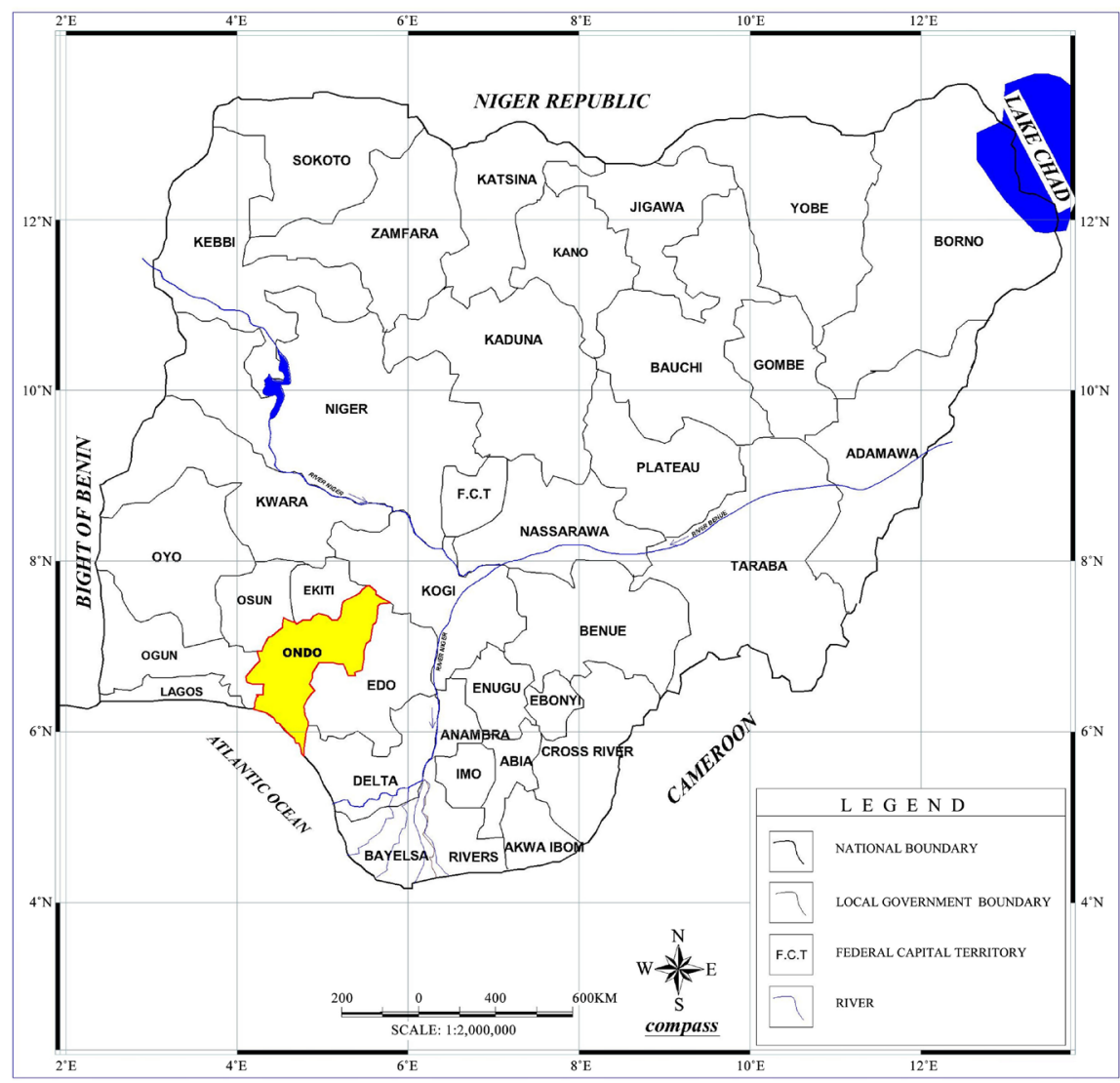

Figure 1. Map of Nigeria showing Ondo state.

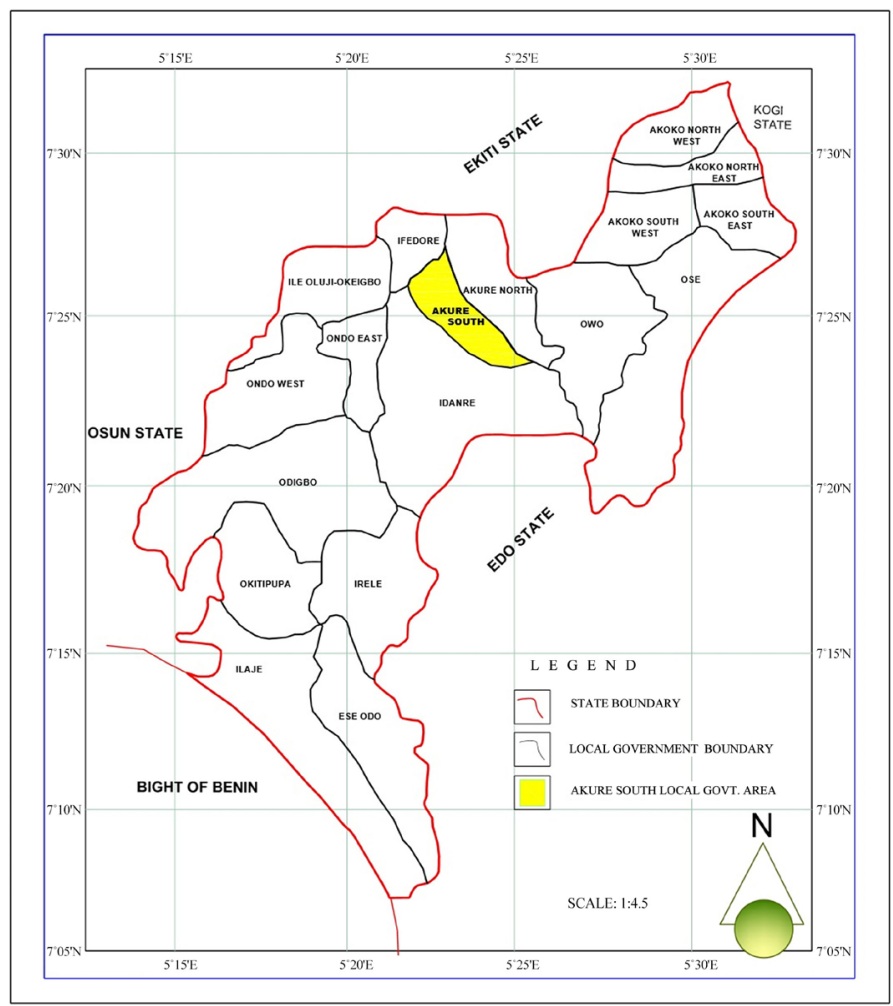

Figure 2. Map of Ondo state showing Akure south local government. 


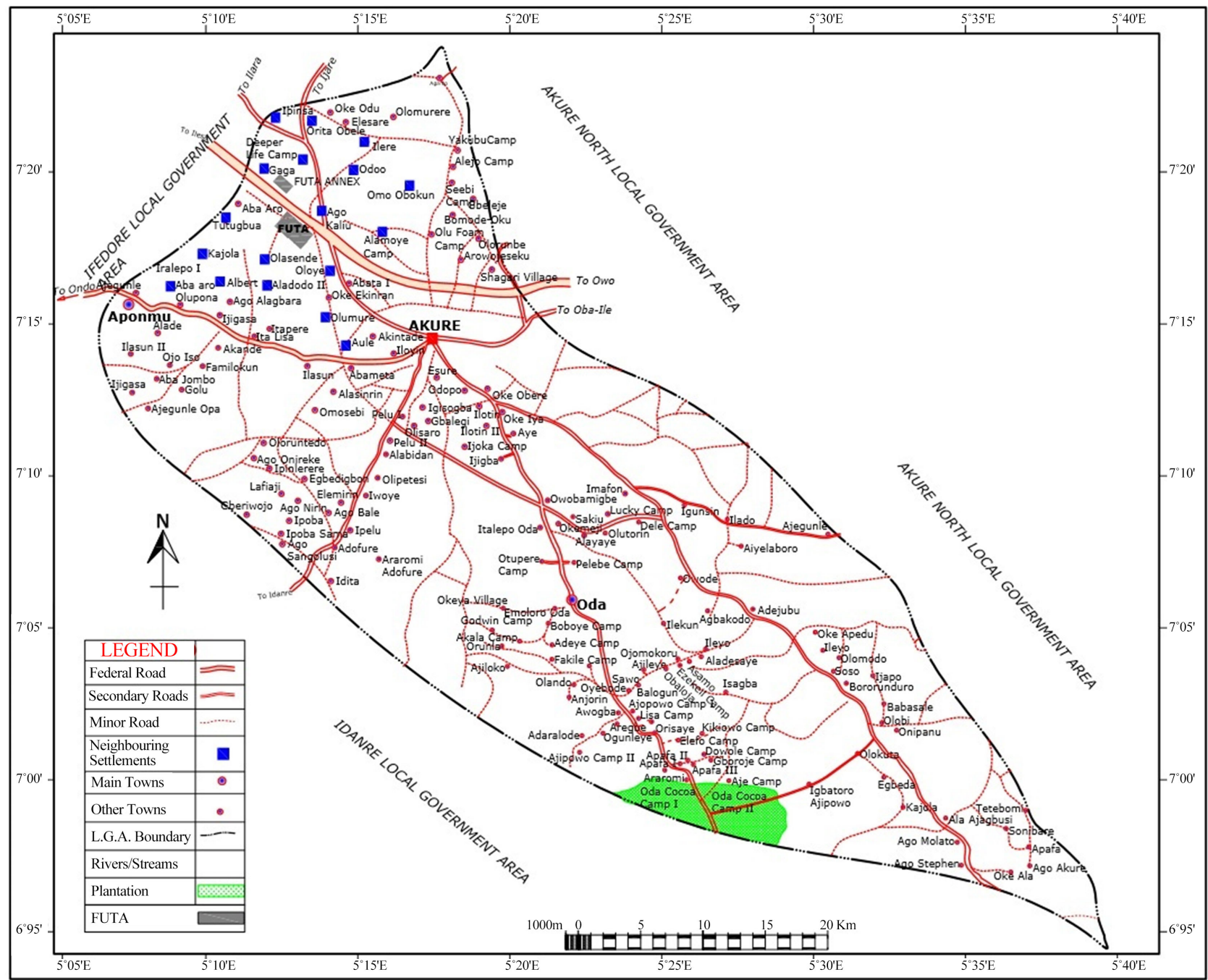

Figure 3. Map showing the location of the study area.

\section{Data Acquisition and Method}

This study was interested in the effect of urban land use change on selected public utilities in Akure. It also seeks to use the capabilities of Geographical Information System and remote sensing techniques to determine the rate of land use change on these utilities in the study area. To achieve this, IKONOS images of Akure were acquired for 2010 and 2018. The images are geometrically corrected and ground control point obtained through intensive ground surveys permitted the co-registration of all images to Universal Transverse Mercator (UTM). The Urban Satellite imageries were made to pass through process of image enhancement, geo referencing, resampling, image classification was performed on false colour composites into the following landuse: residential, commercial and institutional. Information collected during field surveys was combined with the digital topographic map which was developed for the study area was used to assess the accuracy of the classification.

The questionnaire method was used to generate attribute data to further en- 
hance our information on the study. For the purpose of this study, the selected landuse areas are: residential (Oba Afunbiowo and Igoba); commercial (Isikan market, shasha and Akure mall) and institutional (Federal university of Technology, Akure and its environs. The questionnaires were allotted based on the number of buildings in the selected landuse in each area.

Two hundred and forty questionnaires (240) were administered in all out which 200 were retrieved in analyzable form given a response rate of $83.3 \%$. By this the exercise is considered successful. Table 1 shows the residential and the number of questionnaires administered per landuse area.

The data collected using this medium was processed using Statistical Package for Social Scientists software (SPSS). Results obtained were presented in form of tables and Figures. The areas covered by the questionnaire include demographic factors responsible for urban change in the study area. All questions were carefully analysed and considered in addition to spatial information from GIS analysis to arrive at our conclusion.

\section{Results and Discussion}

Three major classifications were used in this study. These are the residential which comprises of the dwelling houses; commercial which include Isikan market, shasha market and Akure mall; and institutional landuse including Federal University of Technology and its environs. However, the total area of each of the landuse was calculated in 2010 and 2018. The total areal extent for each land use type is thus summarized in Table 2. On comparing the Figure 4 and Figure 5 and Table 2, it was observed that the residential landuse (Igoba) covered $7,573,720$ square meters (0.03\%) in 2010 and increased to $19,853,027.32$ square meters (78.23\%) in 2018 which corroborates the work of Eni \& Ukpong (2014) that more demand for residential land due to population growth and increase in proportion of land for residence, while Oba Afunbiowo in Figure 6 and Figure 7 decreased gradually from 1,502,192.16 (0.25\%) in 2010 to 2,747,914.12 square meters $(0.08)$ in 2018. The commercial landuse on the other hand in Figures 8-13

Table 1. Questionnaire administration analysis.

\begin{tabular}{ccccc}
\hline $\begin{array}{c}\text { Landuse } \\
\text { Areas }\end{array}$ & Sampled areas & $\begin{array}{c}\text { No. of } \\
\text { Buildings } \\
\text { in the areas }\end{array}$ & $\begin{array}{c}\text { No. of } \\
\text { Questionnaires } \\
\text { Administered }\end{array}$ & $\begin{array}{c}\text { Questionnaire } \\
\text { Retrieved }\end{array}$ \\
\hline Residential & Obaafunbiowo/Igoba & 301 & 60 & 43 \\
Commercial & $\begin{array}{c}\text { Isikan market/shasha } \\
\text { Market/Akure mall }\end{array}$ & 298 & 60 & 45 \\
Institution & $\begin{array}{c}\text { Federal university } \\
\text { of Technology } \\
\text { and its environs }\end{array}$ & 167 & 60 & 55 \\
Sub-total & & 766 & 240 & 200 \\
\hline
\end{tabular}

Source: Author's survey (2018). 
F. O. Akinluyi et al.

Table 2. Selected Land use change in ( $\mathrm{m}^{2} /$ year) and (\% year) of Akure in 2010 and 2018.

\begin{tabular}{ccccc}
\hline Selected area & $\begin{array}{c}\text { 2010 in } \\
\text { square meters }\end{array}$ & \% in 2010 & $\begin{array}{c}\text { 2018 in } \\
\text { square meters }\end{array}$ & \% in 2018 \\
Futa & $2,161,387.69$ & 19.15 & $2,639,908.44$ & 10.41 \\
Isinkan & 5937.30 & 67.13 & $20,776.61$ & 0.08 \\
Shasha & $28,969.61$ & 0.10 & $83,299.80$ & 0.33 \\
Akure mall & $12,100.17$ & 0.05 & $31,708.78$ & 0.12 \\
Obaafunbiowo & $1,502,192.16$ & 13.32 & $2,747,914.12$ & 10.83 \\
Igoba & $7,573,720.03$ & 0.25 & $19,853,027.32$ & 78.23 \\
Total & $11,284,288.96$ & 100 & $25,376,635.07$ & 100 \\
\hline
\end{tabular}

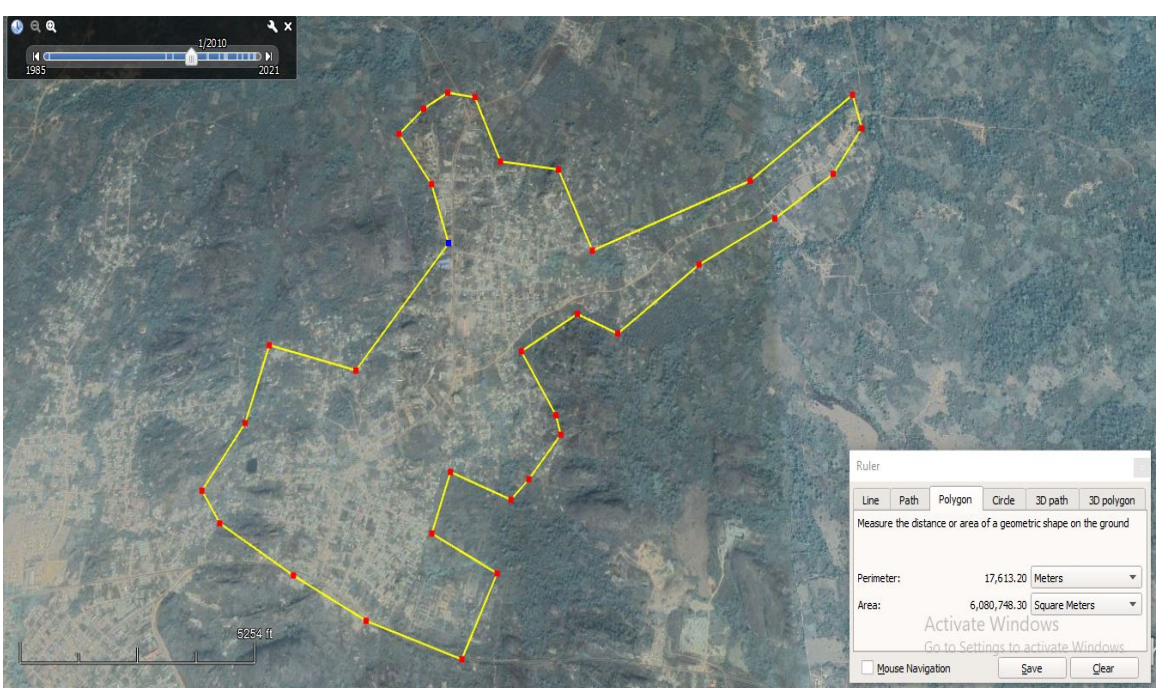

Figure 4. Land area of Igoba Akure in 2010 covering 7,573,720.03 square meters.

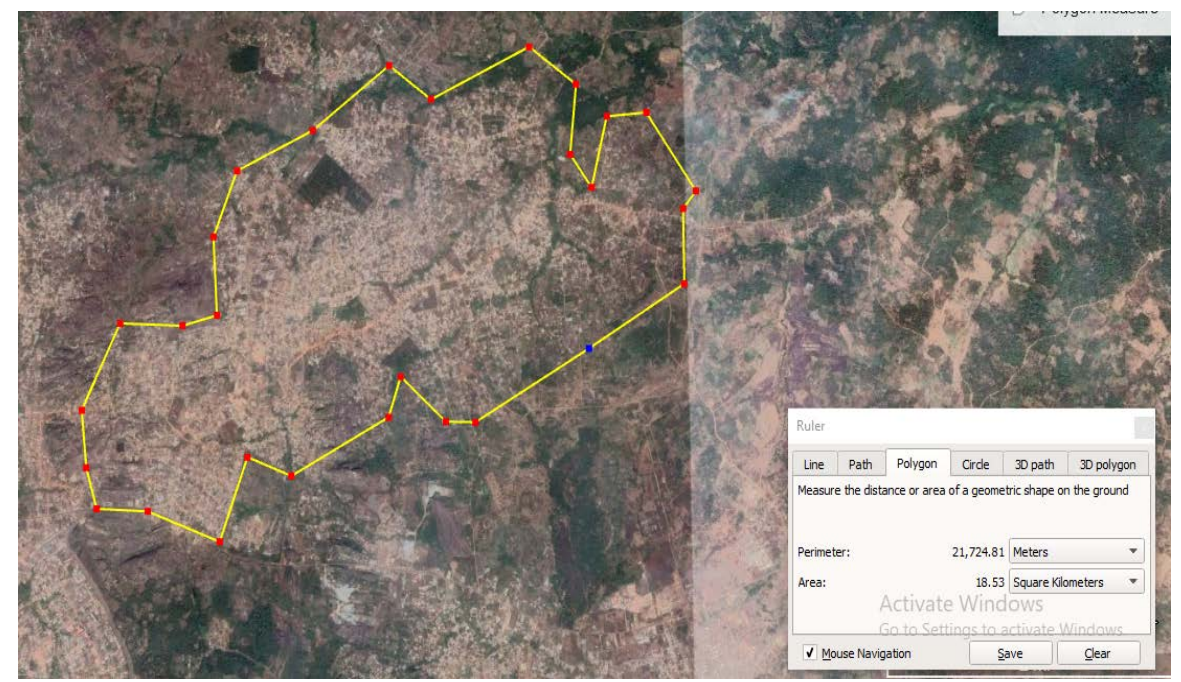

Figure 5. Land area of Igoba, Akure in 2018 covering 19,853,027 square meters. 


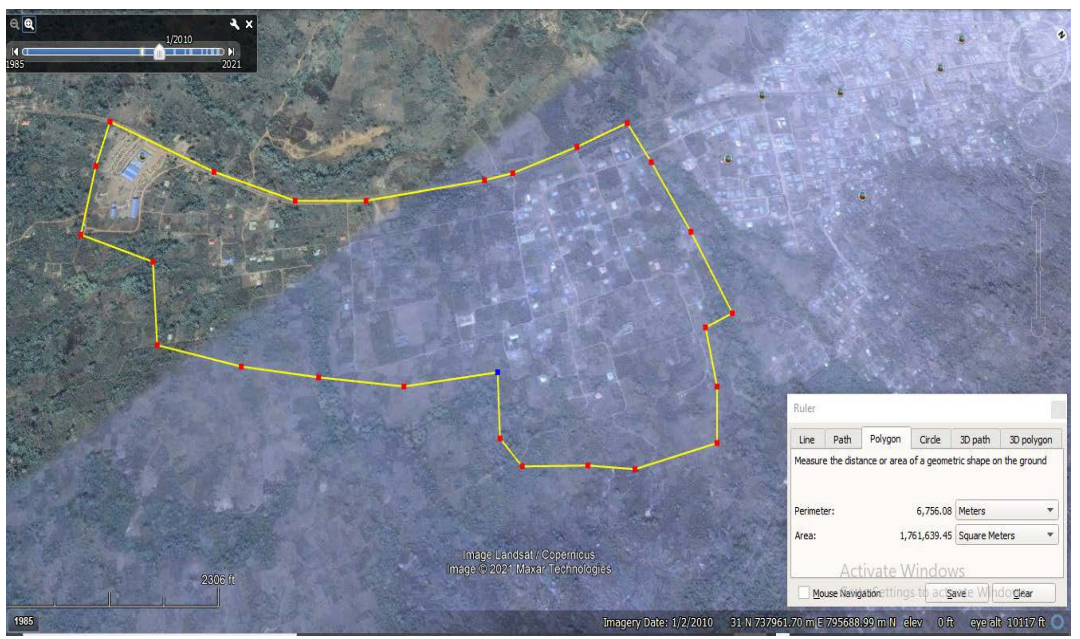

Figure 6. Land area of Oba Afunbiowo Akure in 2010 covering 1,502,192.16 square meters.

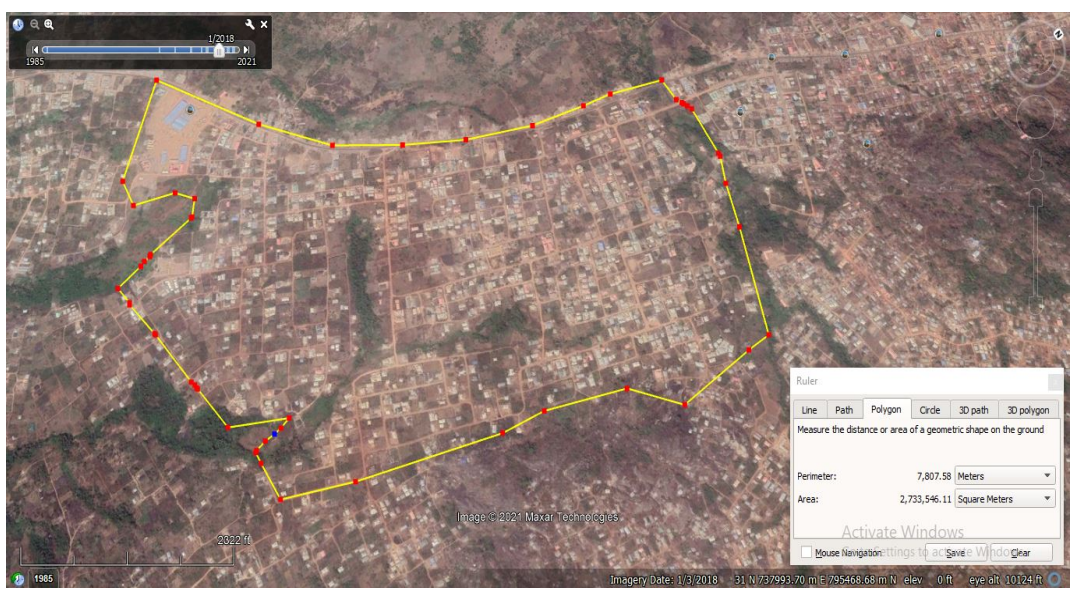

Figure 7. Land area of Obaafunbiowo Akure in 2010 covering 2,747,914.12 square meters.

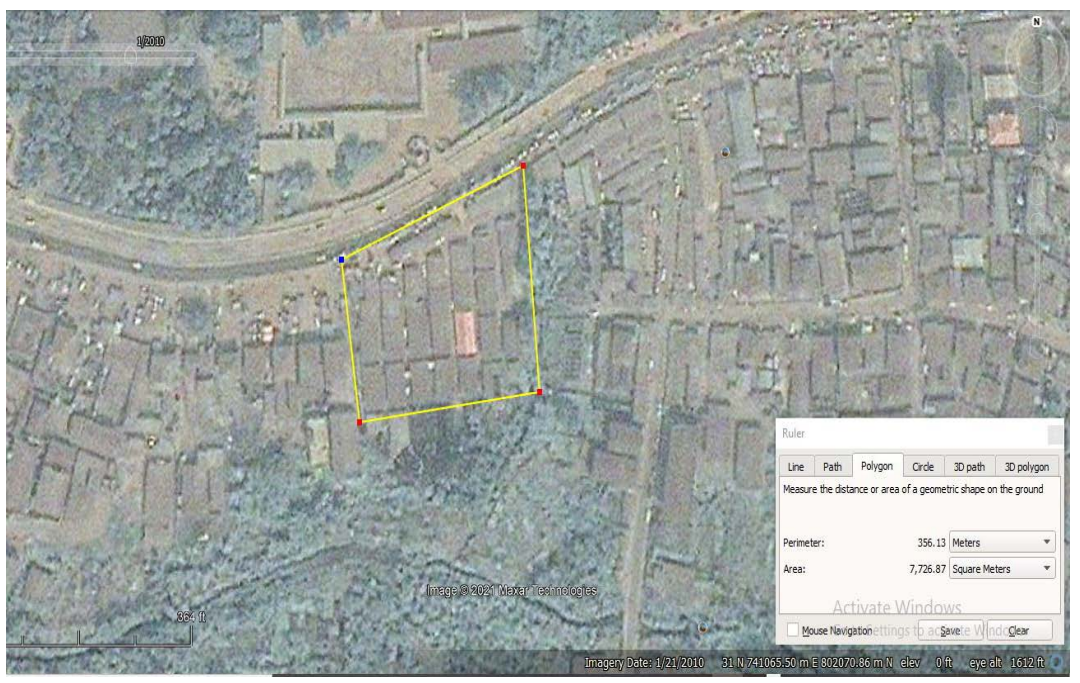

Figure 8. Commercial Land area of Isikan market Akure in 2010 covering 5937.30 square meters. 


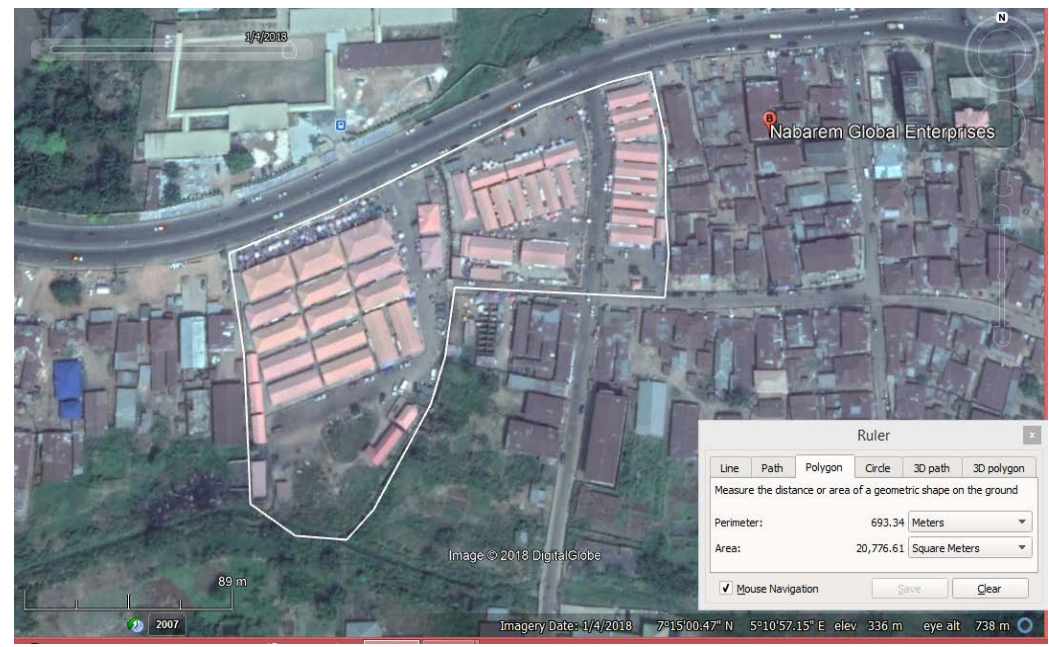

Figure 9. Commercial Land area of Isikan market Akure in 2018 covering 20,776.61 square meters.

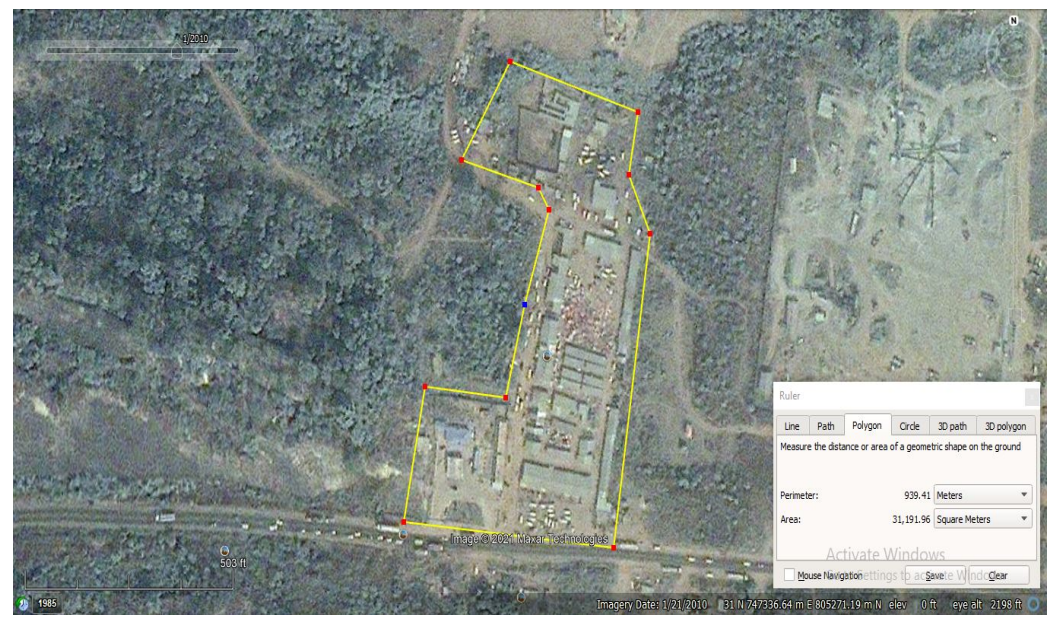

Figure 10. Commercial Land area of shasha market Akure in 2010 covering $28,969.61$ square meters.

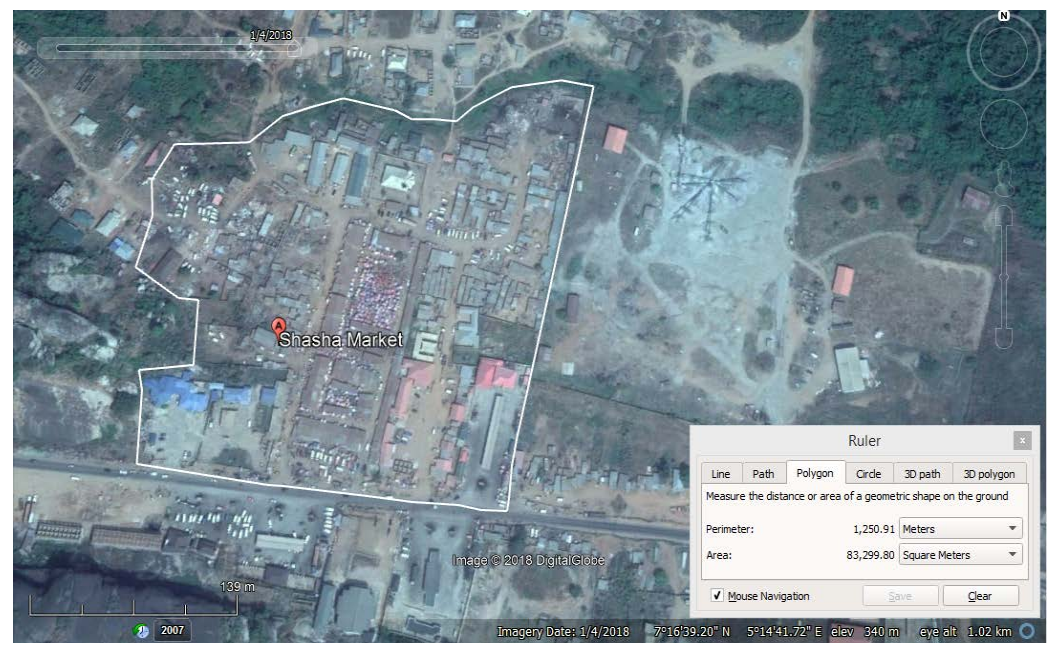

Figure 11. Commercial Land area of Shasha market Akure in 2018 covering $83,299.80$ square meters. 


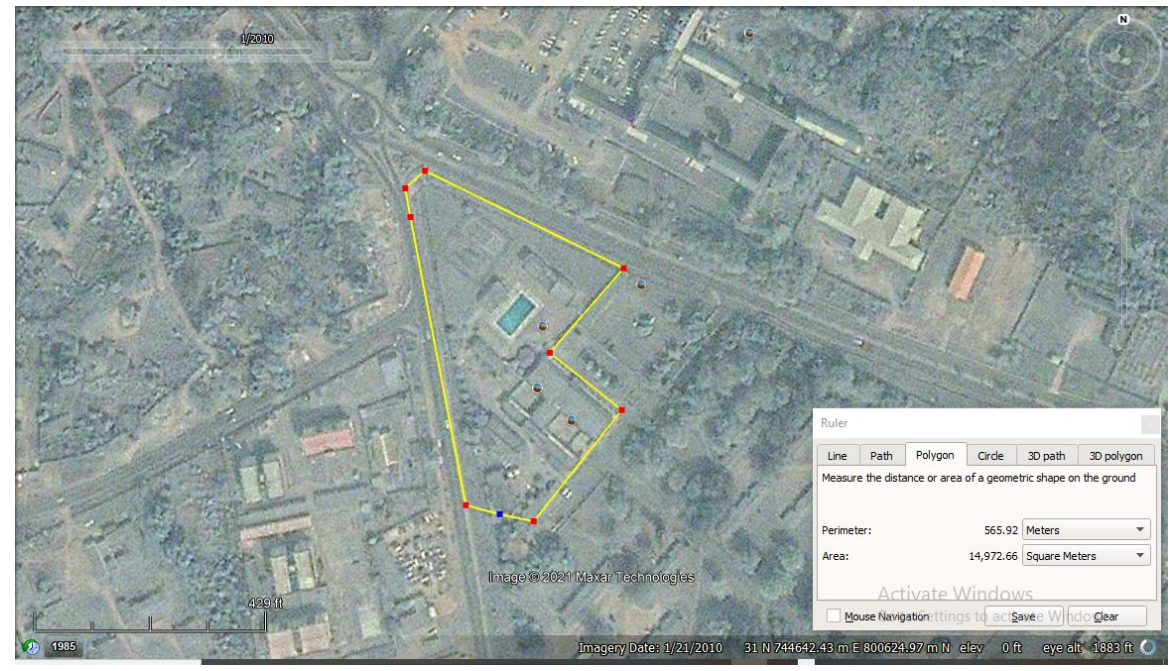

Figure 12. Commercial Land area of Akure mall in 2010 covering 12,100.17 square meters.

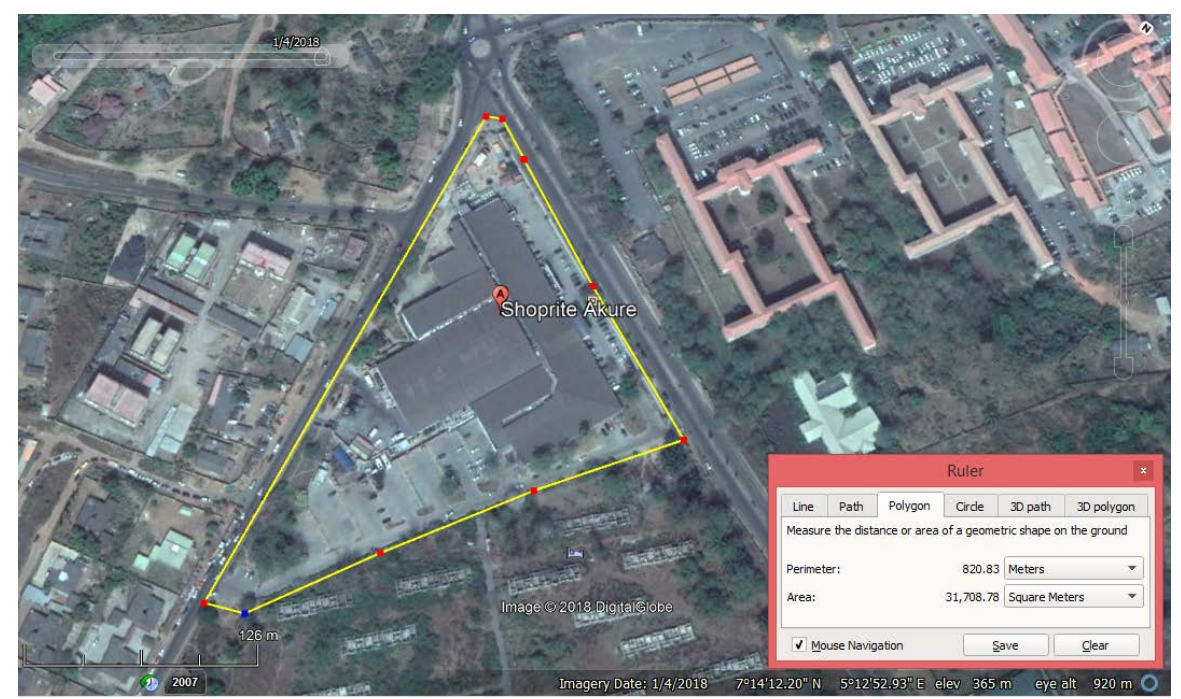

Figure 13. Commercial Land area of Akure mall in 2018 covering 31,708.78 square meters.

due to massive in population affected the landuse change to various conversion of residential use to commercial. The commercial land use change of Isinkan decreased from $5937.30(67.13 \%)$ in 2010 to $20,776.61$ (0.08\%) in 2018 while shasha and Akure mall increased drastically from 28,969 square meters (0.10\%) and $12,100.17$ square meters $(0.05 \%)$ square meters in 2010 to $83,299.80(0.33 \%)$ and $31,708.78$ square meters $(0.12 \%)$ in 2018 respectively which corroborates the work of Appiah et al. (2014) that increasing rate of peri-urbanization caused by rising demand for residential, recreational and commercial land uses to the detriment of agricultural land uses. The institutional land use in Figure 14 and Figure 15 as result of massive encroachment, farming activities and various expansions going on, the landuse change decreased from 21,161,387.69 square meters $(19.15 \%)$ to 2639.908 square meters $(10.41 \%)$ in 2018. 


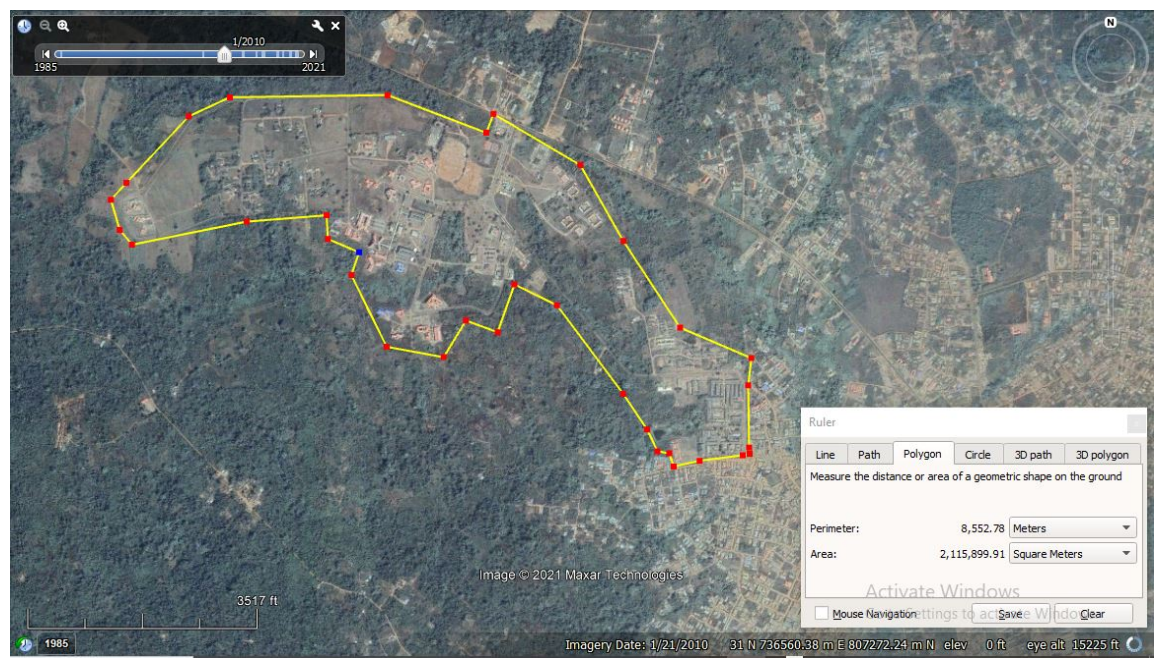

Figure 14. Institutional landuse of Akure in 2010 covering 2,161,387.69 square meters.

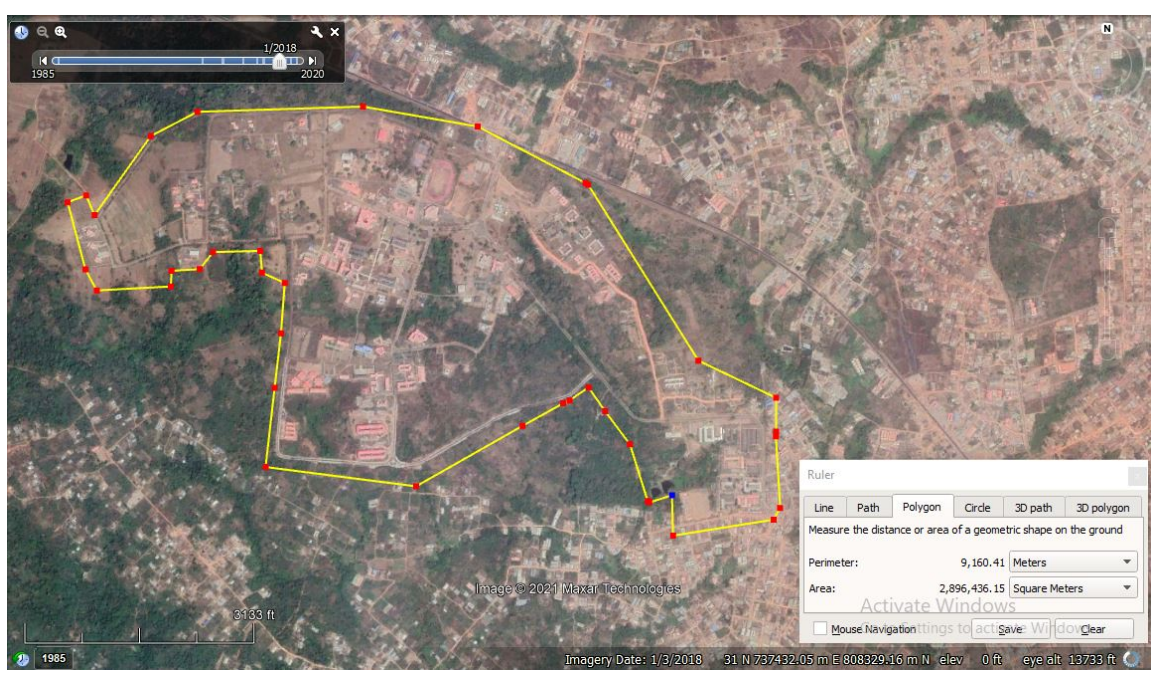

Figure 15. Institutional landuse of Akure in 2018 covering 2,639,908.44 square meters.

\section{Implications of Landuse Change in the Study Area}

A tremendous increase in population as a result of the improved status of Akure from a traditional town to a State capital led to changes in land use pattern, which initially dominated by residential and cultural landuse to a more complex and diversified type of landuse. Institutional, commercial and administrative and social landuses among others were added to the existing landuses. Akure has undergone and is still undergoing many changes in physical form and economic functions in terms of land uses in response to the population growth. There are so many inter-woven factors contributing to this population growth. The creation or establishment of industries created job opportunities which attracted migrants into the town. This has led to changes in residential as well as commercial land use. Furthermore, the creation of higher institution of learning such as The Federal University of Technology has also contributed to population growth which has both directly or indirectly influenced other landuse activities. 
However, the impact of the population growth is also seen in the establishment of new markets and development of the old ones. In essence, the establishment of Shasha market and renovation of Isikan market and Akure mall are due to population growth and urban expansion. One can now be able to infer from the above that population growth in Akure leads to the increase in types and areal extent of urban land use.

Other variables that are responsible for land use changes in the study area include: the type of building; use of building; age of building; and building approval plan before construction among others (see Table 3, Table 7).

Table 3 shows that the bungalow type of building is the most occurring type of building with $36.7 \%$, follow by block of flats also having $25.0 \%$, storey buildings with $20.8 \%$, and lastly followed by duplex with $12.9 \%$, This is an indication that the other building types meant to accommodate large number of people are springing up and this will give rise to population of the study area and other urban problems such as overstretch of infrastructures will then be experienced.

The result of the survey describes the previous uses of buildings in the study before they were converted into new uses as shown in Table 4. This result is a true reflection of what the area is ought to be in its real nature as planned. The survey conducted shows that residential covers about $50.0 \%$, commercial $22.9 \%$, institutional $16.7 \%$, recreational $5.0 \%$ while industrial is $5.4 \%$ respectively. This shows the use at which the study is purposely meant for from inception. This is actually turning to a commercial land area from residential area.

Table 5 also shows the results of the present uses of building in the study area. The result shows that the most dominant use of land is the residential is $53.3 \%$, with commercial $24.2 \%$, institutional $16.3 \%$, recreational $3.3 \%$ and industrial $2.9 \%$. This survey reveals that the extent at which changes have occurred in the study area, this occurrences have not actually stop, so there is possibility that the area will attain another state of commercially developed area in the nearest future. This is an implication that one might not actually be able to ascertain the use of this area in the future to come if the government do not find measure to stop the ongoing change.

Table 6 gives an insight on how the buildings are converted from their previous use to their current use. From the survey carried out in Table 6, it is shown that most conversion are actualised by addition of uses to the previous use that is having mixed-use and this accounts for about $40.0 \%$, followed by change in use from their original use which also account for $24.2 \%$, also alteration of buildings also account for about 15.0\%, partial demolition and renovation accounts for $10.4 \%$ while reconstruction and total demolition accounts for $6.3 \%$ and $4.1 \%$ respectively. The implications of all these indicate that buildings are being converted at an alarming rate.

Table 7 shows that over $50 \%$ of buildings in the study area did not secure building plan approval before construction. Up till the time of this study, there are no plans for most of the buildings in the study area. The situation reveals 
that property owners in the study area develop their properties without due regard to physical planning rules and regulations.

Table 3. Building types.

\begin{tabular}{ccc}
\hline Response & Frequency & $\%$ \\
\hline Bungalow & 88 & 36.7 \\
Storey Building & 50 & 20.8 \\
Duplex & 31 & 12.9 \\
Block of Flats & 60 & 25.0 \\
Others & 11 & 4.6 \\
Total & 240 & 100.0 \\
\hline
\end{tabular}

Table 4. Former use of building.

\begin{tabular}{ccc}
\hline Response & Frequency & $\%$ \\
\hline Residential & 120 & 50.0 \\
Commercial & 55 & 22.9 \\
Institutional & 40 & 16.7 \\
Recreational & 12 & 5.0 \\
Industrial & 13 & 5.4 \\
Total & 240 & 100.0 \\
\hline
\end{tabular}

Table 5. Present use of building.

\begin{tabular}{ccc}
\hline Response & Frequency & $\%$ \\
\hline Residential & 128 & 53.3 \\
Commercial & 58 & 24.2 \\
Institutional & 39 & 16.3 \\
Recreational & 8 & 3.3 \\
Industrial & 7 & 2.9 \\
Total & 240 & 100.0 \\
\hline
\end{tabular}

Table 6. Present use of building.

\begin{tabular}{ccc}
\hline Response & Frequency & $\%$ \\
\hline Mixed use & 96 & 40.0 \\
Change in use & 58 & 24.2 \\
Alteration in buildings & 36 & 15.0 \\
Partial demolition and renovation & 25 & 10.4 \\
Reconstruction & 15 & 6.3 \\
Total demolition & 10 & 4.1 \\
Total & 240 & 100.0 \\
\hline
\end{tabular}


Table 7. Building plan approval before construction.

\begin{tabular}{ccc}
\hline Approval & Frequency & $\%$ \\
\hline Yes & 110 & 45.8 \\
No & 130 & 54.2 \\
Total & 240 & 100.0 \\
\hline
\end{tabular}

\section{Conclusion and Recommendation}

The study has revealed on the percentage basis the various landuse categories in the study area. It is clearly seen that the residential and commercial are the most extensive landuse found in the study area. The reason for the high proportion of residential land use is the absence of other activities which is present in the large and medium towns, with this; one can easily infer that Akure falls to the categories of medium towns, since it has over $78.23 \%$ of its land area occupied by residential units. Furthermore, the study reveals that the total area covered by residential cum commercial is greater than the total area occupied by the remaining landuse activities combined together as shown in Table 2. The result of the study shows about $10.41 \%$ of the total area in 2018 . These institutions are usually located at the outskirts of Akure metropolis where the huge land requirement is available. Example of this is Federal University of Akure.

The landuse changes done in this study displayed what exists in the urban scape of selected areas of Akure has therefore shown that the current landuse situation is such that can lead to ecological disaster. The study therefore advances some recommendations as a way of preventing these problems. First, the urban developer should be in conformity with planning regulations. People should be aware of such regulations to serve as a guide and rule for them in building of their houses both in terms of spacing and distance away from the roads. Second. Land conservation act should emphasis systematic growth of the city. Third, population growth through immigration should be controlled through the policy of regional development programme.

\section{Conflicts of Interest}

The authors declare no conflicts of interest regarding the publication of this paper.

\section{References}

Adebayejo, A. T., \& Abolade, O. (2006). Analysis of Spatial Changes in Ogbomoso City. Journal of the NITP, XIX, 35-47.

Adegoke, O. J. (2014). Critical Factors Determining Rental Value of Residential Property in Ibadan Metropolis, Nigeria. Property Management, 32, 224-240. https://doi.org/10.1108/PM-05-2013-0033

Adeniyi, P. O. (1978). Some Fundamental Issues in Land and Land Use Planning in Nigeria. The Nigeria Geographical Journal, 22, 59-79.

Alonso, W. (1960). A Theory of the Urban Land Market. Papers and Proceedings of the 
Regional Science Association, 6, 149-157. https://doi.org/10.1111/j.1435-5597.1960.tb01710.x

Appiah, D. O., Bugri, J. T., Forkuor, E. K., \& Boateng, P. K. (2014). Determinants of Peri-Urbanization and Land Use Change Patterns in Peri-Urban Ghana. Journal of Sustainable Development, 7, 95-108. https://doi.org/10.5539/jsd.v7n6p95

Edwards, M. E. (2007). Regional and Urban Economics and Economic Development. Boca Raton, FL: Auerbach Publications, Taylor and Francis Group.

Eni, D. D., \& Ukpong, B. J. (2014). The Impact of Population Growth on Residential Landuse in Calabar, Cross River State. Research on Humanities and Social Sciences, 4, 68-74.

Goetz, S. J., Shortle, J. S., \& Bergstrom, J. C. (Eds.) (2005). Land Use Problems and Conflicts: Causes, Consequences and Solutions. Oxon: Routledge, Taylor \& Francis Group.

Jensen, J. R., Cowen, D., Narumalani, S., \& Halls, J. (2003). Principle of Change Direction Using Digital Remote Sensor Data. In J. L. Star, J. E. Estes, \& K. C. McGwire (Eds.), Integration of Geographic Information System and Remote Sensing (34-54). Cambridge: Cambridge University Press.

Kabba, V. T., \& Li, J. (2011). Determinants of Urban Land Price in Freetown, Sierra Leone. Journal of American Science, 7, 213-223.

Kamh, S., Ashmawy, M., Kilias, A., \& Christaras, B. (2012). Evaluating Urban Land Cover Change in the Hurghada area, Egypt, by using GIS and Remote Sensing. International Journal of Remote Sensing, 33, 41-68. https://doi.org/10.1080/01431161.2010.550331

Lee, C., Huang, S., \& Chan, S. (2009). Synthesis and Spatial Dynamics of Socio-Economic Metabolism and Land Use Change of Taipei Metropolitan Region. Ecological Modelling, 220, 2940-2959. https://doi.org/10.1016/j.ecolmodel.2009.06.021

Musaogwu, N., Kaya, S., Seker, D. Z., \& Goksel, C. (2002). A Case Study of Using Remote Sensing Data and GIS for Land Management; Catalca Region. FIG XXII International Congress, Washington DC, 19-26 April 2002, 1-9.

National Population Commission (NPC) (2006). Population of the Federal Republic of Nigeria. Analytical Report at the National Level, Abuja.

Peng, G., \& Howarth, P. (2004). The Use of Structural Information for Improving LandCover Classification Accuracy at Rural-Urban Fringe. Photogrammetric Engineering and Remote Sensing, 56, 67-73.

Ramadan, E., Feng, X.-Z., \& Cheng, Z. (2004). Satellite Remote Sensing for Urban Growth Assessment in Shaoxing City, Zhejiang Province. Journal of Zhejiang University Science (English Edition), 5, 1095-1101. https://doi.org/10.1631/jzus.2004.1095

Uju, I. V., \& Iyanda, S. T. (2012). Comparative Analysis of the Determinants of Residential Land Values. Chinese Business Review, 11, 187-192.

Yin, Z.-Y., Steward, D. J., Bullard, S., \& MacLachlan, J. T. (2005). Changes in Urban Built-Up Surface and Population Distribution Patterns during 1986-1999: A Case Study of Cairo, Egypt. Computer, Environment and Urban System, 29, 595-616. https://doi.org/10.1016/j.compenvurbsys.2005.01.008

Zubair, A. O. (2006). Change Detection in Land use and Land cover Using Remote Sensing Data and GIS (A Case Study of Ilorin and Its Environs in Kwara State). Nigeria: The Department of Geography, University of Ibadan. 